\title{
Extracorporeal membrane oxygenation programs for COVID-19 in China
}

\author{
Chenglong $\mathrm{Li}^{1}$, Xiaotong Hou ${ }^{1 *}$, Zhaohui Tong ${ }^{2}$, Haibo $\mathrm{Qiu}^{3}$, Yimin $\mathrm{Li}^{4}$, Ang $\mathrm{Li}^{5}$ and Chinese Society of \\ Extracorporeal Life Support (CSECLS)
}

Dear Editor,

The outbreak of coronavirus disease (COVID-19) was first reported in Wuhan, the capital city of Hubei province, and may lead to severe pneumonia and acute respiratory distress syndrome (ARDS). Extracorporeal membrane oxygenation (ECMO), as a temporary life support technique for refractory respiratory or cardiac failure, has been applied in COVID-19 patients [1]. However, the impact of ECMO on outcomes from COVID-19 was controversial. Referring to the present case series and the COVID-19 cohort in China, the mortality of patients undergoing ECMO ranged from 42 to 83\% [2, 3]. The Chinese Society of Extracorporeal Life Support (CSECLS) performed a survey of ECMO programs for COVID-19 in China, aimed at investigating the program organization and the potential factors associated with outcomes during the pandemic.

This voluntary survey was disseminated via e-mail and WeChat to 365 ECMO programs registered with the CSECLS on March 23, 2020. Through March 29, we had received 350 individual responses from 270 (74.0\%) ECMO programs in total. When analyzing program characteristics, the program directors' or coordinators' responses were adopted.

One hundred eleven individual responses from 79 ECMO programs (30 in Hubei and 49 outside Hubei) applied ECMO in patients with COVID-19 pneumonia and ARDS were analyzed. Respondents included those located in 25 provinces within China before COVID-19 outbroke. Twenty-seven respondents belonged to the medical assistance teams which were dispatched to aid Hubei and 39 respondents aided other hospitals in their original province, while 45 respondents managed COVID-19 patients with ECMO within their original hospitals. Fifty-one of 79 ECMO programs (15 in Hubei and 36 outside Hubei) were organized temporarily in response to the crisis. Thirty-two hospitals with temporary ECMO programs did not have any ECMO cases before. The geographic distribution of the 79 ECMO programs and responders' aid to Hubei is shown in Fig. 1. Patient management characteristics are illustrated in Table 1. Compared with ECMO programs in Hubei, more programs outside Hubei initiated ECMO in older patients ( $36.7 \%$ vs $3.3 \%$ in age $\geq 75, p=0.001 ; 55.1 \%$ vs $26.7 \%$ in age $65-74, p=0.014$ ).

Our findings provide evidence of the current condition of ECMO programs for COVID-19 across China. Fifty-one ECMO programs were newly organized. It was most efficient to rearrange medical workers and resources rather than starting new ECMO programs amid the crisis, given that inexperienced ECMO programs and hospitals might lead to unfavorable outcomes. Since ECMO is a complicated and highrisk therapy, adequate training and high-volume experience are indispensable [4].

We also found a difference in age between ECMO patients in Hubei and outside Hubei. Seventy-five percent of COVID-19 cases in China were diagnosed in Hubei [5]. With limited medical resources in Hubei, patients with a higher likelihood of survival were chosen to receive ECMO, namely younger patients. However, medical resources were adequate outside Hubei. That might be the main reason for more ECMO programs outside Hubei applied ECMO in older patients (age > 65), aiming

\footnotetext{
* Correspondence: xt.hou@ccmu.edu.cn

${ }^{1}$ Center for Cardiac Intensive Care, Beijing Anzhen Hospital, Capital Medical

University, 2 Anzhen Rd, Chaoyang District, Beijing 100029, China

Full list of author information is available at the end of the article
}

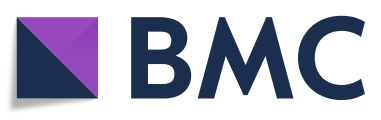

(c) The Author(s). 2020 Open Access This article is licensed under a Creative Commons Attribution 4.0 International License, which permits use, sharing, adaptation, distribution and reproduction in any medium or format, as long as you give appropriate credit to the original author(s) and the source, provide a link to the Creative Commons licence, and indicate if changes were made. The images or other third party material in this article are included in the article's Creative Commons licence, unless indicated otherwise in a credit line to the material. If material is not included in the article's Creative Commons licence and your intended use is not permitted by statutory regulation or exceeds the permitted use, you will need to obtain permission directly from the copyright holder. To view a copy of this licence, visit http://creativecommons.org/licenses/by/4.0/ The Creative Commons Public Domain Dedication waiver (http://creativecommons.org/publicdomain/zero/1.0/) applies to the data made available in this article, unless otherwise stated in a credit line to the data. 


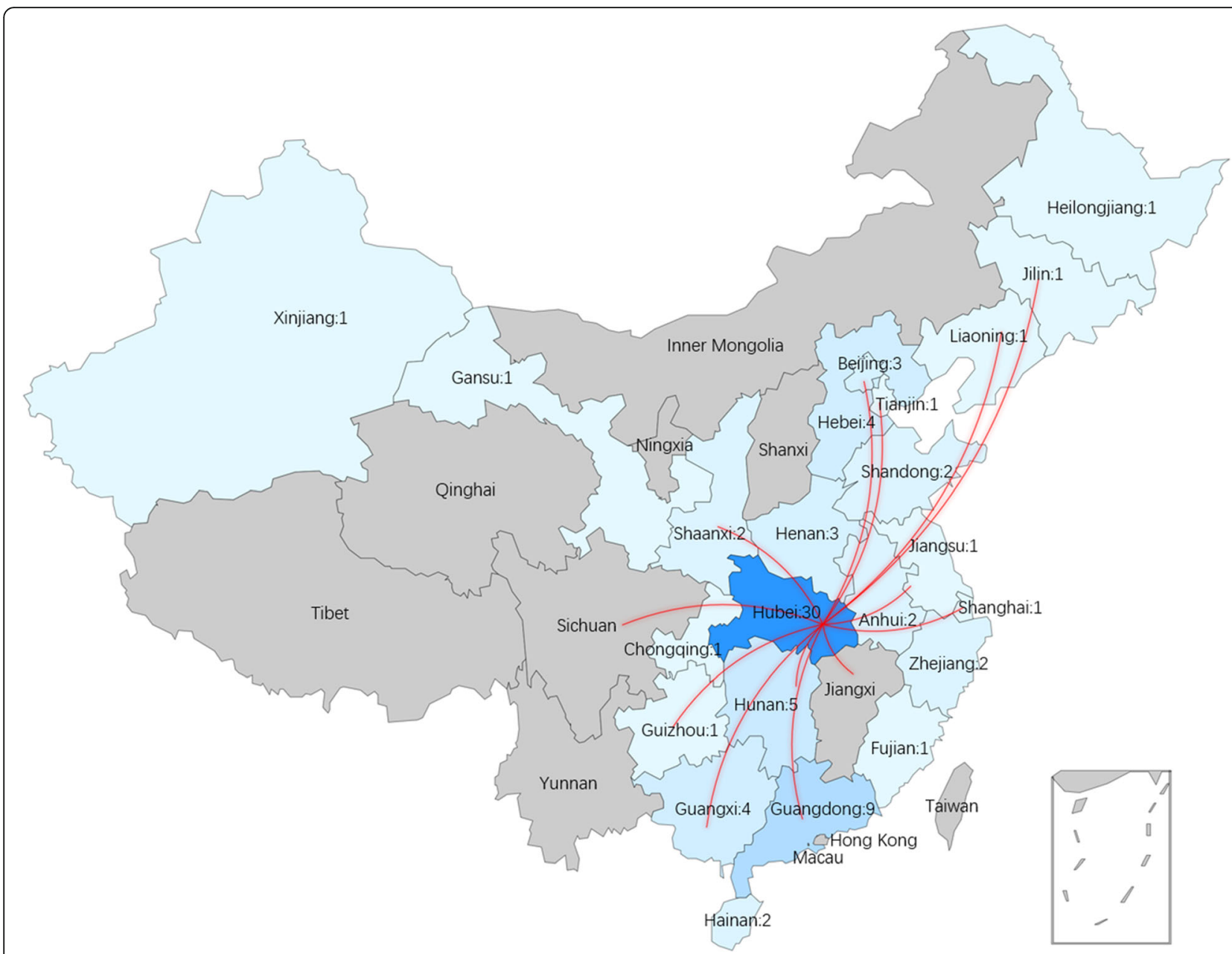

Fig. 1 The geography distribution of ECMO programs for COVID-19 in China. The total 79 ECMO programs for COVID-19 by province (with the number of ECMO programs in each province) and respondents' aid to Hubei from other provinces (red lines) were shown 
Table 1 Patient management responded by ECMO programs

\begin{tabular}{|c|c|}
\hline Question & Total ECMO programs, $n=79[n(\%)]$ \\
\hline \multicolumn{2}{|l|}{ ECMO cases for COVID-19 } \\
\hline$\leq 5$ & $68(86.1 \%)$ \\
\hline$>5$ & $11(13.9 \%)$ \\
\hline \multicolumn{2}{|l|}{ The source of ECMO patients for COVID-19 } \\
\hline In-hospital patient & $62(78.5 \%)$ \\
\hline Transferred from other hospitals, then initiated ECMO & $24(30.4 \%)$ \\
\hline Initiated ECMO in other hospitals, then transferred & $8(10.1 \%)$ \\
\hline \multicolumn{2}{|l|}{ Initiated ECMO in COVID-19 patients whose age } \\
\hline$<65$ & $54(68.4 \%)$ \\
\hline $65-74$ & $35(44.3 \%)$ \\
\hline$\geq 75$ & $19(24.1 \%)$ \\
\hline \multicolumn{2}{|l|}{ Therapy before ECMO initiation } \\
\hline Recruitment maneuvers & $65(82.3 \%)$ \\
\hline Neuromuscular blockers & $64(81.0 \%)$ \\
\hline Prone position & $61(77.2 \%)$ \\
\hline \multicolumn{2}{|l|}{ Therapy after ECMO initiation } \\
\hline Recruitment maneuvers & $56(70.9 \%)$ \\
\hline Neuromuscular blockers & $61(77.2 \%)$ \\
\hline Prone position & $61(77.2 \%)$ \\
\hline Bronchoscopy & $59(74.7 \%)$ \\
\hline CT scan & $40(50.6 \%)$ \\
\hline
\end{tabular}

ECMO extracorporeal membrane oxygenation, $C T$ computer tomography

at minimizing the local mortality of COVID-19. Age is a key driver of mortality, helping clinicians to select the most appropriate candidates for ECMO among severe ARDS patients [6]. However, age should be reconsidered in the discussions of indications for ECMO in COVID19. To the limitation, the patient's detailed characteristic was not obtained in the present study. Further multicenter registry on COVID-19 patients receiving ECMO support would be performed.

To summarize, our large national survey provided detailed information regarding the organization of ECMO programs for COVID-19 in China. To improve outcomes with ECMO during the pandemic, it is key to provide information about ECMO experience, patient selection, and resource allocation to ECMO programs throughout the world.

\section{Abbreviations}

COVID-19: Coronavirus disease 2019; CSECLS: Chinese Society of Extracorporeal Life Support; CT: Computer tomography

\section{Authors' contributions}

$\mathrm{CL}$ and $\mathrm{XH}$, manuscript writing; $\mathrm{XH}$, study design; $\mathrm{CL}$, data collection and analysis; TZ, QH, LY, and LA, manuscript revision. The authors read and approved the final manuscript.

\section{Funding \\ This work was supported by the National Key Research and Development Program of China (No. 2016YFC1301001).}

\section{Availability of data and materials}

The datasets used in the present study are available from the first author and corresponding authors on reasonable request.

Ethics approval and consent to participate

Institutional ethics oversight was considered unnecessary since the present study was a voluntary survey.

\section{Consent for publication \\ Not applicable.}

\section{Competing interests}

None.

\section{Author details \\ ${ }^{1}$ Center for Cardiac Intensive Care, Beijing Anzhen Hospital, Capital Medical University, 2 Anzhen Rd, Chaoyang District, Beijing 100029, China. \\ ${ }^{2}$ Department of Respiratory and Critical Care Medicine, Beijing Institute of Respiratory Medicine, Beijing Chao-yang Hospital, Capital Medical University, Beijing, China. ${ }^{3}$ Department of Critical Care Medicine, Zhongda Hospital, School of Medicine, Southeast University, Jiangsu, China. ${ }^{4}$ The State Key Laboratory of Respiratory Diseases, Guangzhou Institute of Respiratory Health, The First Affiliated Hospital of Guangzhou Medical University, Guangdong, China. ${ }^{5}$ Department of Critical Care Medicine, Beijing Ditan Hospital, Capital Medical University, Beijing, China.}


Received: 17 May 2020 Accepted: 28 May 2020

Published online: 08 June 2020

\section{References}

1. MacLaren G, Fisher D, Brodie D. Preparing for the most critically ill patients with COVID-19: the potential role of extracorporeal membrane oxygenation. JAMA. 2020;323(13):1245-6.

2. Yang $X, Y u Y, X u$ J, Shu H, Xia J, Liu H, Wu Y, Zhang L, Yu Z, Fang M, et al. Clinical course and outcomes of critically ill patients with SARS-CoV-2 pneumonia in Wuhan, China: a single-centered, retrospective, observational study. Lancet Respir Med. 2020;8(5):475-81.

3. Zeng Y, Cai Z, Xianyu Y, Yang BX, Song T, Yan Q. Prognosis when using extracorporeal membrane oxygenation (ECMO) for critically ill COVID-19 patients in China: a retrospective case series. Crit Care. 2020;24(1):148.

4. Barbaro RP, Odetola FO, Kidwell KM, Paden ML, Bartlett RH, Davis MM, Annich GM. Association of hospital-level volume of extracorporeal membrane oxygenation cases and mortality. Analysis of the extracorporeal life support organization registry. Am J Respir Crit Care Med. 2015;191(8): 894-901.

5. Wu Z, McGoogan JM. Characteristics of and important lessons from the coronavirus disease 2019 (COVID-19) outbreak in China: summary of a report of 72314 cases from the Chinese Center for Disease Control and Prevention. JAMA. 2020;323(13):1239-42.

6. Schmidt M, Bailey M, Sheldrake J, Hodgson C, Aubron C, Rycus PT, Scheinkestel C, Cooper DJ, Brodie D, Pellegrino V, et al. Predicting survival after extracorporeal membrane oxygenation for severe acute respiratory failure. The Respiratory Extracorporeal Membrane Oxygenation Survival Prediction (RESP) score. Am J Respir Crit Care Med. 2014;189(11):1374-82.

\section{Publisher's Note}

Springer Nature remains neutral with regard to jurisdictional claims in published maps and institutional affiliations.

Ready to submit your research? Choose BMC and benefit from:

- fast, convenient online submission

- thorough peer review by experienced researchers in your field

- rapid publication on acceptance

- support for research data, including large and complex data types

- gold Open Access which fosters wider collaboration and increased citations

- maximum visibility for your research: over $100 \mathrm{M}$ website views per year

At $\mathrm{BMC}$, research is always in progress.

Learn more biomedcentral.com/submissions 